\title{
Editorial
}

\section{Conociendo al COVID-19 y la labor odontológica ante la pandemia}

\section{Getting to know COVID-19 and dental work in the pandemic}

Fernando Suaste-Olmos 1,a, María Verónica Cuevas-González 2,b, Alma Graciela García Calderón ${ }^{3, c}$, Juan Carlos Cuevas González 3,d

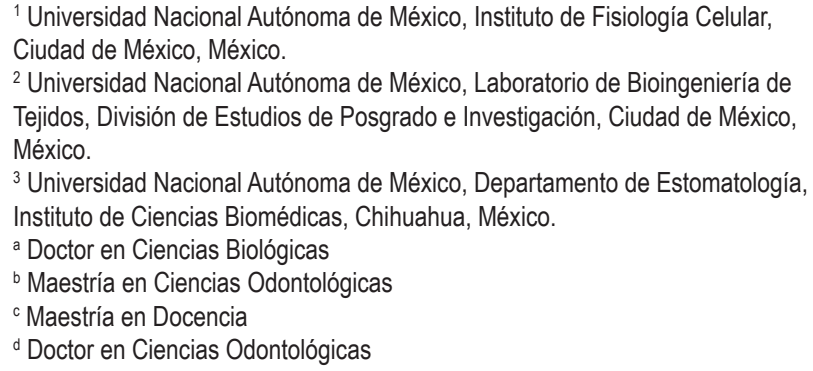

\section{Correspondencia:}

Juan Carlos Cuevas González: juan.cuevas@uacj.mx

Av. Benjamín Franklin no. 4650, Zona Pronaf Condominio La Plata, 32310 Cd Juárez, Chih.

ORCID: 0000-0002-6981-8025

\section{Coautores:}

Fernando Suaste-Olmos: fsuaste@ifc.unam.mx ORCID: 0000-0002-7013-7315

María Verónica Cuevas-González: cuevas_veronica@live.com.mx ORCID: 0000-0003-3112-4893

Alma Graciela García Calderón: alma.garcia@uacj.mx ORCID: 0000-0002-6297-3567
En febrero del presente año la Organización Mundial de la Salud (OMS) dio a conocer la presencia de una nueva cepa de un virus que estaba generando enfermedades respiratorias altamente contagiosas, el COVID-19, ;pero qué es este virus? Los coronavirus $(\mathrm{CoVs})$ son una familia de virus con genoma RNA pertenecientes al orden Nidovirales, los cuales se han clasificado en tres subgrupos $\alpha, \beta, y \gamma$, los subtipos " $\alpha$ " y " $\beta$ " se encuentran distribuidos en mamíferos, incluyendo humanos y el subtipo " $\gamma$ " en aves, sin embargo, un cuarto grupo denotado como " $\delta$ " ha sido reclasificado debido a su capacidad de infectar porcinos ${ }^{1}$; estos subtipos de coronavirus se caracterizan principalmente por generar enfermedades de tipo respiratorio y gastrointestinales ${ }^{2}$. Recientemente dos tipos de coronavirus que infectan humanos (HCoVs), denominados como SARS-CoV (por sus siglas en inglés Severe Acute Respiratory Syndrome Coronavirus) y MERS-CoV (Middle East Respiratory Syndrome Coronavirus) han generado brotes epidemiológicos durante el 2002 y 2012 respectivamente que han afectado severamente la salud en humanos ${ }^{3}$, por lo cual su estudio a nivel molecular y genético se ha intensificado en los últimos años, específicamente por el aislamiento de la nueva cepa de coronavirus designada COVID-19. Estructuralmente los coronavirus son de forma ovoide con un diámetro aproximado de $80-120 \mathrm{~nm}$, poseen una envoltura formada por un conjunto de espículas denotadas como "peplomeros" que mimetizan la corona solar, de ahí su nombre de familia Coronaviridae. Los coronavirus $(\mathrm{CoVs})$ poseen el genoma más largo entre las familias de virus de RNA ( 26-32 kb), este genoma se caracteriza por poseer una hebra de RNA con polaridad positiva no segmentada, la cual tiene una organización bien definida y conservada entre los integrantes del orden Nidovirales ${ }^{4}$.

La envoltura de los CoVs está conformada por cuatro tipos de proteínas: 1) la glicoproteína "S" o proteína 
"Spike" (por su denotación en inglés), la cual permite la unión y fusión a la célula receptora, es una proteína transmembranal, con un peso molecular de $\sim 150-200$ $\mathrm{kDa}$. Topológicamente, posee un largo dominio N-terminal orientado hacia el exterior de la envoltura viral, en donde se llevan a cabo la glicosilación de múltiples residuos de aminoácidos y un dominio de fusión, mientras que la porción C-terminal se orienta hacia el interior de la envoltura viral; 2) la glicoproteína de Membrana "M", una proteína de $\sim 25-30 \mathrm{kDa}$ con múltiples dominios transmembranales, constituye el principal elemento de andamiaje que permite dar forma a los CoVs; 3) la proteína de Envoltura "E", con un peso de $\sim 12$ $\mathrm{kDa}$, representa el elemento menos abundante de la envoltura viral, de la cual, aún no se ha elucidado con precisión su papel como elemento estructural o de regulación, sin embargo, evidencia experimental ha sugerido un papel relevante tanto en la maduración y virulencia del virus; finalmente 4) la proteína de la Nucleocápside "N" ( 43-50 kDa), constituye el primer elemento estructural que se asocia al genoma de RNA del virus, conformando el núcleo del genoma viral (nucleocápside) ${ }^{4,5}$. El mecanismo descrito por el cual el COVID-19 infecta las células es por medio de la glicoproteína $S$, la cual tiene como principal receptor a la enzima convertidora de angiotesina-2 (ACE-2), una vez establecida la unión, el virus se introduce a la célula huésped liberando su carga viral (RNA) ${ }^{6}$.

Las principales vías de transmisión para este virus son los fluidos provenientes del tracto respiratorio y cavidad bucal que se liberan al hablar, toser o estornudar, así como los aerosoles. La práctica odontológica es sin duda alguna un foco peligroso de posible transmisión debido al manejo directo de la saliva y de los aerosoles que se producen en los diversos procedimientos odontológicos, pero ¿Cuál es el papel del odontólogo ante esta enfermedad? Esto se responde 1) estableciendo las barreras de protección adecuadas, 2) delimitando los tratamientos de emergencia en pacientes vulnerables y 3) brindando la información adecuada al paciente.

Las medidas de protección son la base para evitar la diseminación de la enfermedad, medidas de seguridad las podemos enfocar para el operador, el paciente y para el equipo e instrumental. El o los operadores se deben proteger con el uso de guantes, mascarillas, lentes protectores y/o caretas, así como batas quirúrgicas. Se recomienda utilizar técnica a seis manos para tener un mejor control, las cuales consisten en el operador principal, el asistente y un asistente circulante el cual se encarga del tránsito del equipo o instrumental al sitio operador con la finalidad de evitar la contaminación en todo el consultorio. Por otra parte, las medidas de seguridad para el paciente se enfocan en el aislamiento correcto de los órganos dentales a tratar utilizando dique de hule el cual reduce los aerosoles en un $70 \%$, en caso necesario de forma adicional se pueden utilizar campos quirúrgicos desechables que aíslen la superficie facial del paciente, si el paciente es de alto riesgo se recomienda el uso de bata desechable. Finalmente, en los cuidados hacia el equipo e instrumental se recomienda el uso de aspiradores de alta velocidad o quirúrgicos, el empleo de anti-retracción en las piezas de mano de alta velocidad que evite la contaminación hacia las mangueras de la pieza de mano y la unidad dental. La desinfección del equipo e instrumental es vital, ya que se ha demostrado que este tipo de virus llega a sobrevivir en superficies de metal, acero o aluminio desde 4 horas hasta 5 días y en superficies plásticas sobrevive hasta por 9 días, por lo que la esterilización por calor de todo el instrumental debe ser obligatorio, ya que se ha demostrado que esta familia de virus cuando se exponen a temperaturas de alrededor de $75^{\circ} \mathrm{C}$ por un período de tiempo de 30 minutos pierden su potencial de infección, así como la limpieza de las superficies con solución de hipoclorito de sodio al $0,1 \%$ o etanol al $70 \%$ durante 1 minuto ${ }^{7,8}$. Si bien estas medidas de seguridad deben formar parte de la práctica diaria, ante los brotes de pandemias se deben aplicar de forma estricta y constante.

El identificar a pacientes vulnerables o bien con altas probabilidades de presentar la enfermedad por COVID-19 es de gran importancia, ya que de esto dependerá la atención que se brinde; pacientes de edad avanzada, con presencia de comorbilidades como diabetes o enfermedad cardiovascular deberán ser considerados como pacientes vulnerables. Aquellos pacientes que presenten fiebre, tos seca así como fatiga, entre otras características ${ }^{9}$ deberán ser considerados con alto potencial de presentar la enfermedad por COVID-19. Todos estos pacientes que no requieran tratamiento de emergencia se recomienda que la atención odontológica sea pospuesta hasta que su estado de salud lo permita reanudar o bien los sistemas de salud locales retiren el periodo de aislamiento, sin embargo, si se llega a presentar alguna urgencia como fractura de órganos dentarios, pulpitis irreversibles, neuralgias, entre otros, deberán ser tratados siguiendo todas las medidas de bioseguridad ya mencionadas.

Finalmente es necesario educar al paciente sobre los cuidados bucales que se deben de tener durante todo el periodo que dure la pandemia, la higiene bucal se debe de mantener tres veces al día, usando cepillo dental, pastal dental e hilo dental, limitar el consumo de alimentos con alto contenido de azúcares para evitar el desarrollo de caries. Instruir al paciente que el uso de enjuagues bucales con alcohol no evita el contagio del virus, por lo que no son recomendados.

En conclusión, el desarrollo del virus COVID-19 está poniendo a prueba los sistemas de salud y a todo el personal médico a nivel global. Aún falta mucha investigación acerca de la patogenia del virus en diferentes poblaciones del mundo, de tal forma que permita un mejor entendimiento y manejo de la enfermedad. El odontólogo debe estar preparado para identificar y tratar en caso de ser estrictamente necesario, a los pacientes vulnerables e infectados; las barreras de protección se deben implementar todo el tiempo para evitar infecciones cruzadas, sin embargo, en este periodo de tiempo deben de ser mucho más rigurosas. 


\section{Referencias bibliográficas}

1. Marthaler D, Raymond L, Jiang Y, Collins J, Rossow K, Rovira A. Rapid Detection, Complete Genome Sequencing, and Phylogenetic Analysis of Porcine Deltacoronavirus. Emerg Infect Dis. 2014 Aug;20(8):1347-50.

2. González JM, Gomez-Puertas P, Cavanagh D, Gorbalenya $\mathrm{AE}$, Enjuanes L. A comparative sequence analysis to revise the current taxonomy of the family Coronaviridae. Arch Virol. 2003 Nov;148(11):2207-35.

3. Coleman CM, Frieman MB. Coronaviruses: Important Emerging Human Pathogens. J Virol. 2014 May 15;88(10):5209-12.

4. Masters PS. The Molecular Biology of Coronaviruses. Adv Virus Res. 2006;65:193-292.

5. Fehr AR, Perlman S. Coronaviruses: An overview of their replication and pathogenesis. Coronaviruses Methods Protoc. 2015 Feb 26;1282:1-23.

6. Guo Y-R, Cao Q-D, Hong Z-S, Tan Y-Y, Chen S-D, Jin $\mathrm{H}-\mathrm{J}$, et al. The origin, transmission and clinical therapies on coronavirus disease 2019 (COVID-19) outbreak - an update on the status. Mil Med Res [Internet]. 2020 Mar 13 [citado el 23 de marzo del 2020];7(1):11. Disponible en: http://www.ncbi.nlm.nih.gov/pubmed/32169119
7. Kampf G, Todt D, Pfaender S, Steinmann E. Persistence of coronaviruses on inanimate surfaces and their inactivation with biocidal agents. J Hosp Infect. 2020 Mar $1 ; 104(3): 246-51$.

8. Henwood AF. Coronavirus disinfection in histopathology. J Histotechnol [Internet]. 2020 Mar 1 [citado el 24 de marzo del 2020];1-3. Disponible en: https://www. tandfonline.com/doi/full/10.1080/01478885.2020.173 4718

9. Han R, Huang L, Jiang H, Dong J, Peng H, Zhang D. Early Clinical and CT Manifestations of Coronavirus Disease 2019 (COVID-19) Pneumonia. Am J Roentgenol [Internet]. 2020 Mar 17 [citado el 23 de marzo del 2020];(10.2214/AJR.20.22961):1-6. Disponible en: https://www.ajronline.org/doi/10.2214/AJR.20.22961 
